\title{
Nesting Behavior and Prey Use in Two Geographically Separated Populations of the Specialist Wasp Symmorphus cristatus (Vespidae: Eumeninae)
}

\author{
ANNA L. W. SEARS ${ }^{1,2,6}$, JOHN T. SMILEY,4, MONIKA HILKER ${ }^{5}$, FRANK MÜLLER ${ }^{5}$ AND \\ NATHAN E. RANK ${ }^{2,4}$ \\ ${ }^{1}$ Department of Evolution and Ecology, University of California, Davis 95616 \\ ${ }^{2}$ Department of Biology, Sonoma State University, Rohnert Park, California 94928 \\ ${ }^{3}$ Big Creek Reserve, Big Sur, California 93920 \\ ${ }^{4}$ White Mountain Research Station, 3000 East Line Street, Bishop, California 93514 \\ ${ }^{5}$ Insitute for Biology/Animal Ecology, Free University of Berlin, Haderslebenerstrasse 9,
} Berlin, Germany D-12163

\begin{abstract}
The food web of Symmorphus cristatus wasps, leaf beetle larvae (Coleoptera: Chrysomelidae) and willow (Salix spp.) trees is a model system for studying the chemical ecology of plant, herbivore and predator interactions. However, little is known about the natural history and prey use of the predatory wasps. We conducted detailed observations of nesting behavior and quantified time allocation to nest building activities in Big Pine Creek in the eastern Sierra of California. Symmorphus cristatus exhibits aggressive territorial behavior over nesting and mating sites, but does not respond aggressively to kleptoparasitism by cuckoo wasps Chrysis nitidula. We also compared prey use, nest provisioning and nest architecture of wasps at Big Pine Creek and at Sebastopol, near the central California coast. Using trap-nests we identified two new prey species for $S$. cristatus at Sebastopol: Plagiodera californica and Chrysomela schaefferi (Coleoptera: Chrysomelidae). There were significant differences in nest architecture for the two allopatric wasp populations and, although they do not use the same prey species, populations did not differ in the mean mass of prey provided for each offspring. Five other cavity-dwelling insect species pre-empted nest sites in Sebastopol. Prey species in Sebastopol differ in the chemistry of their larval secretion. The main component of $C$. schaefferi secretion is salicylaldehyde, which is derived from the willow host plants. Plagiodera californica secretion contains (epi) plagiolactone, an autogenously produced monoterpene-based defensive secretion. This is the first evidence that $S$. cristatus uses prey larvae that possess a monoterpene-based secretion.
\end{abstract}

\section{INTRODUCTION}

Over the past 100 y ecologists and evolutionary biologists have sought to understand how the vast diversity of insect taxa is generated and maintained. Many of the hypotheses to explain this diversity involve trophic specialization and divergence following geographic isolation. A related mechanism is the "coevolutionary arms race" hypothesized by Ehrlich and Raven (1964), where plants and lower-level consumers develop chemical defense mechanisms to reduce predation, and their specialist predators evolve metabolic and behavioral means to tolerate this chemical defense. The food web of Symmorphus wasps, chrysomeline leaf beetles and willow (Salix) tree species has become a model system for studying both chemical defense mechanisms and the evolution of specialization (e.g., Eisner and Meinwald, 1966; Wallace and Blum, 1969; Pasteels et al., 1983; Pasteels et al., 1984; Pasteels and Gregoire, 1984; Smiley et al., 1985; Smiley and Rank, 1986; Denno et al., 1990; Kearsley and Whitham, 1992; Rank et al., 1996). Whereas considerable attention has been focused on

${ }^{6}$ Corresponding author: Telephone (530) 752-3717, FAX (530) 752-1449, e-mail: alsears@ucdavis.edu

I have chacked this proof. I huve merised all chinges or

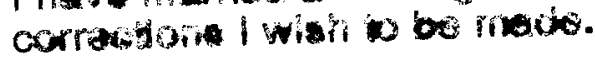
Signed 
the plant-herbivore interaction, much less is known about the specialist predators of these herbivores.

Many species of predatory wasps obtain herbivorous insect prey to provision nests for the larval stages of their offspring and usually specialize to some degree. Within the vespid subfamily Eumeninae some wasp species use only aphids to feed their offspring, whereas others specialize on lepidopteran or coleopteran larvae (Krombein et al., 1979). With few exceptions, wasps in the genus Symmorphus prey only on the larvae of leaf beetles (Chrysomelidae: Chrysomelinae; Cumming, 1989). These beetle larvae have external glands from which they release strong-smelling volatile secretions (Hinton, 1951; Eisner and Meinwald, 1966; Wallace and Blum, 1969; Pasteels et al., 1984). Symmorphus wasps occur throughout the northern Hemisphere and have been recorded as predators of at least fifteen leaf beetle species in Asia, Europe and North America (Smith, 1858; Fabre, 1891; Berland, 1928; Jolivet, 1950; Blüthgen, 1961; Fye, 1965; Smereka, 1965; Krombein, 1967; Krombein et al., 1979; Richards, 1980; Smiley and Rank, 1986; Bonelli, 1989; Yamane, 1990; Hamanishi, 1996).

Symmorphus cristatus ranges across most of southern Canada and the northern U.S.A., as well as the mountains of California, Utah and Arizona (Krombein et al., 1979). This is a particularly interesting species because, across its range, $S$. cristatus is opportunistic in its prey-use (using different prey species in different regions) while remaining highly specialized in prey choice (each wasp population was previously documented to use a single prey species). In the northeast, $S$. cristatus populations use Chrysomela scripta, $C$. crotchi and Gonioctena americana (Krombein et al., 1979). Studies beginning in 1982 revealed that Symmorphus cristatus was a significant predator on the larvae of the leaf beetle Chrysomela aeneicollis at high elevations $(2500-3500 \mathrm{~m})$ in the eastern Sierra Nevada of California (North Fork Big Pine Creek, Inyo County; 37.7'N, 188.7'W; Smiley and Rank, 1986). The three Chrysomela species derive their defensive secretion from salicylates, found as secondary compounds in their Salicaceae host-plants (Pasteels et al., 1983). Gonioctena americana produces a secretion whose chemistry has not been determined, but larvae of $G$. viminalis emit autogenously derived secretions (Dettner and Schwinger, 1987).

In 1997 we located a population of Symmorphus cristatus in the low-elevation $(25 \mathrm{~m})$ coastal regions north of the San Francisco Bay (Sebastopol, Sonoma County; 38.4' $\mathrm{N}$, $122.8^{\prime} \mathrm{W}$ ). This gave us an opportunity to compare two populations living in distinctly different habitats, some $600 \mathrm{~km}$ apart. Although $S$. cristatus occurs in both locations, its Sierran prey, Chrysomela aeneicollis, is not found in coastal California.

Cavity-nesting hymenopterans are often assumed to be limited by nesting sites (e.g., Barthell et al., 1998). Their labor-intensive nest architecture requires a large investment of time and energy on the part of adult females and has been used in the past to characterize different wasp species. The population-level impacts of wasp predation on their prey species will be constrained by the ability of wasps to build and provision nests. Thus, wasp nesting behavior is a critical component of their ecology. Most of our current information about the prey use and nest architecture of eumenine wasps comes from studies of Krombein and other workers who placed artificial nests into natural environments and recollected them after the wasps had filled them with prey (see Parker and Bohart, 1966; Krombein, 1967). This technique also allows researchers to rear adult wasps (cf., Chilcutt and Cowan, 1993). Previous studies have shown patterns in prey allocation, cell size and cell position for male and female offspring (Fabre, 1921; Krombein, 1967; Cowan, 1981). Cells containing female offspring tend to be at the rear (inner most portion) of the nest and are larger and more heavily provisioned than cells containing male offspring. These studies have also provided an overall picture of large-scale differences among wasp species. With current statistical 
packages it is now possible to compare individual and population-level differences in rest architecture and prey provisioning.

In August 1998 we made behavioral observations of Symmorphus cristatus nest building and provisioning habits at Big Pine Creek. We hypothesized: (1) wasp nest building would occur as a defined set of behaviors that are adaptations to capturing and provisioning beetle larvae; and (2) that wasps in dense populations compete for nest sites. Using trap-nests at both field sites we tested the hypotheses that: (3) populations differ significantly in nesting behavior and nest architecture; (4) that inner cells of $S$. cristatus nests are larger and more heavily provisioned than outer cells; and (5) that $S$. cristatus will use chrysomeline beetle species with chemically different volatile secretions.

Natural history.-Symmorphus cristatus is an univoltine wasp of the eumenine group (Cumming, 1989). Adults are nectar feeders, preferring inflorescences of Apiaceae (Smiley and Rank, 1986), such as fennel (Foeniculum vulgare), Queen Anne's lace (Daucus carota), cow parsnip (Heracleum lanatum) and swamp whiteheads (Sphenosciadum capitellatum). Symmorphus nests consist of a linear progression of mud-capped cells, constructed in empty holes made in trees by wood-boring beetles. There are three types of cells in the nest: provisioned cells containing developing wasps, empty intercalary cells placed between provisioned cells, and vestibular cells which form an empty chamber before the end plug. In provisioned cells, the mother wasp will lay an egg near the rear wall, attached to the roof of the cell by a fine thread. After she provisions a cell with paralyzed beetle larvae, the female wasp builds a thin, cup-shaped, mud end wall to seal the cell. After all cells are built, the mouth of the nest is closed off with a thick (3-10 mm) mud plug (Krombein, 1967).

\section{METHODS}

\section{DIRECT OBSERVATIONS OF SYMMORPHUS CRISTATUS BEHAVIOR}

Nest provisioning behavior--To observe nesting behavior under natural conditions we selected the central portion of a fallen lodgepole pine (Pinus contorta) log at the Falls Site of Big Pine Creek that was riddled with bore-holes ranging in diameter between 1.5 to 7 $\mathrm{mm}$ (see Smiley and Rank, 1991 for detailed information about this site). We labeled 42 nest holes and 32 female wasps. We also marked 50 males found in the vicinity of the log. Wasps were captured while they exited nesting holes (females), or with a net (males), and marked for identification with small spots of enamel paint. We then observed nesting behavior during sunny warm hours of six consecutive days (9 to 14 August, 1998). Air temperatures ranged from 20 to $22 \mathrm{C}$. The log was in sun between 0700 and $1100 \cdot \mathrm{h}$ and in partial shade the rest of the day. Occasional cloudy weather interrupted wasp activity, particularly in the afternoon. We typically concentrated on three focal nests that were located within $20 \mathrm{~cm}$ of each other and about $50 \mathrm{~cm}$ from the observer. The observer (J.S.) recorded the time and activity of each wasp in the vicinity of the nests under observation. Data from focal nests were plotted on chart paper. These plots were segmented into discrete sequences, based on when a particular activity began and ended. If a sequence was interrupted for more than $30 \mathrm{~s}$, we did not include it in the analysis. Thirty-eight sequences were analyzed to determine the duration and timing of nesting activities. One of the focal nests was an artificial trap-nest that had been placed on top of the log, the rest were natural nests.

We recorded Symmorphus cristatus nest hole occupancy on 17 Aug. and 5 Sept. 1998 and again on 13 Aug. and 18 Sept. 1999. Nests were recorded as "open" or "plugged." Holes which were observed to be plugged at least once in the two year period were considered to be suitable for occupancy by $S$. cristatus. Holes plugged with resin (made by an uniden- 
tified aphid-hunting wasp) were not recorded. This small black wasp uses smaller holes, usually less than $2 \mathrm{~mm}$ in diameter.

\section{PREY USE AND NEST ARCHITECTURE}

Trap-nest collection and species identification.-We set out trap-nests with $4.8 \mathrm{~mm}$ holes (see Krombein, 1967) in June of 1997 and 1998. Six trap-nests were set out each year at Big Pine Creek, twenty trap-nests were set out in Sebastopol in 1997 and twenty-five trap-nests were set out in 1998. We hung traps in bundles of four to six and checked them weekly for wasp activity. As traps were filled by wasps we set out new ones to replace them. Beetle larvae were identified to species by $N$. E. Rank; wasps were identified by $R$. M. Bohart and bees were identified by R W. Thorp, both of the Bohart Museum of Entomology, University of California, Davis.

Nest architecture analysis. - To analyze trap-nest contents and architecture we counted the number of larvae used to provision each cell, and measured each cell length in millimeters. Cell lengths were compared using an analysis of covariance (ANCOVA) of the $\log _{10}$ (cell length). To test the hypothesis that wasps build longer cells toward the rear of the trap we used a multifactor model. We examined how cell length was affected by position in the trap (the covariate), locality (Big Pine Creek vs. Sebastopol) and individual trap (a random effect nested in locality). Two Sebastopol traps containing larvae of mixed beetle species were analyzed separately.

Cell provisioning analysis. - To compare cell occupancy between the two populations we calculated the percentage of occupied cells in each trap and performed one-way ANOVA. To compare cell provisioning between populations we weighed 235 intact beetle larvae from 10 of the 25 traps and calculated the mean mass of beetle larvae used to provision the cells. We calculated the provisioning mass per cell by multiplying the mean larval mass for a given cell by the number of larvae used to provision that cell. This procedure was necessary because wasp larvae had often already emerged and begun to eat the beetle larvae, leaving shriveled carcasses whose initial mass could not be determined. The provisioning data were analyzed by ANCOVA, with provisioning mass per cell as the dependent variable. The categorical independent variables were population and trap, and cell position was the continuous covariate. We tested for heterogeneity of slopes for the cell-by-weight linear relationship using interactions between the covariate and two categorical variables: cell position-bypopulation and a cell-by-trap interaction. The two Sebastopol traps containing larvae of mixed species were again analyzed separately. All statistical tests were performed using JMP IN version 3.2.1 statistical software.

Prey chemistry analysis.-Larval secretions of Plagiodera californica and Chrysomela schaefferi were collected into glass capillary tubes which were sealed by melting the ends. Secretions were rinsed from the capillaries by a small volume of dichloromethane. One microliter of this solution was injected at $240 \mathrm{C}$ into a gas chromatograph (Fisons 8060) which was coupled to a mass spectrometer (Fison MD 800 quadrupole, EI-mode, $70 \mathrm{eV}$ ). The sample was separated on a DB 5 fused silica column $(30 \mathrm{~m}, 0.32 \mathrm{~mm}$ id, film thickness $0.25 \mu \mathrm{m}$, JW Scientific, USA) with helium as carrier gas (pressure $10 \mathrm{kPa}$ ). The temperature program started at $40 \mathrm{C}$. Temperature was held for $4 \mathrm{~min}$ and raised $3 \mathrm{C} / \mathrm{min}$ (secretion of $C$. schaefferi) or $10 \mathrm{C} / \mathrm{min}$ (secretion of $P$. californica) to $280 \mathrm{C}$. Mass spectra of the main components of the secretion were either directly compared to those of synthetic components (salicylaldehyde and benzaldehyde, Sigma Aldrich, Germany) or to literature data of known major components of chrysomelid larval secretion (plagiolactone, Meinwald et al., 1977; Sugawara et al., 1979). 
TABLE 1.-Sample sizes (nest holes, wasps and the number of behavioral sequences) and mean (SD) time allocation by $S$. cristatus females to principal nest building activities

\begin{tabular}{|c|c|c|c|c|}
\hline \multirow[b]{2}{*}{ Activity } & \multicolumn{3}{|c|}{ Sample size } & \multirow[b]{2}{*}{$\begin{array}{l}\text { Length of activity } \\
\text { (min) }\end{array}$} \\
\hline & Nest holes & Female wasps & $\begin{array}{l}\text { Behavioral } \\
\text { sequences }\end{array}$ & \\
\hline Searching & & & 3 & $15(10)$ \\
\hline Nest preparing & & & 4 & $56(11)$ \\
\hline Egg laying & & & 5 & $13(10)$ \\
\hline Cell provisioning & & & 8 & $66(45)$ \\
\hline Closing cell & & & 10 & $55(27)$ \\
\hline Foraging & & & $\mathbf{5}$ & $47(18)$ \\
\hline Nest plugging & & & 3 & $39(23)$ \\
\hline TOTAL & & & & 291 \\
\hline
\end{tabular}

\section{RESULTS}

\section{DIRECT OBSERVATIONS OF S. CRISTATUS BEHAVIOR}

Nest building and provisioning behavior.-In agreement with our first hypothesis, wasps exhibited a defined set of nest building behaviors that are adaptations for provisioning their offspring with beetle larvae. We were able to assign many observed behaviors to specific activities that the wasp must complete to provision her nest (e.g., the behavior of carrying mud has been assigned to the activity of wall building).

To search for a nest a female examines several holes, hovering and landing, sometimes going inside for several seconds. She usually does not enter holes in active use by other females, or if she enters she leaves immediately. The mean time estimate for searching (Table 1) is a minimum figure since two wasps were searching before they were observed. After identifying a suitable nest, the female spends some time inside. In some cases the wasp pulled material out of the nest and dumped it outside, presumably to clean it. In other cases, the female brought water to moisten dried mud that was blocking the entrance to a nest. Familiarizing and cleaning takes approximately an hour, even in the case of a previously unused hole.

Actual egg-laying is hidden from view, but, in many cases, the wasp crawled out of the hole and backed in to attach her egg at the rear of the chamber. Assuming that egg laying is immediately followed by provisioning with prey, egg-laying time can be estimated. After egg laying, the female sometimes flew in and out of the nest once or twice. Females then flew away for 3-20 min, returning with a third instar Chrysomela aeneicollis larva. The wasp forced prey into the hole and flew away within 20-60 s. She returned at regular intervals with prey until 3-6 beetle larvae were brought in. Completely provisioning a nest may take two or more days, depending on weather, number of cells in the nest and prey availability. Female wasps often spend the night in the open nest, and may resume hunting the next day if a cell is not completely provisioned.

During cell provisioning the cell is open and vulnerable to nest parasitism by cuckoo wasps (Chrysis nitidula). It is likely that hunting females provision the cell as quickly as possible to close it in the shortest time. During our observations, 39 prey were brought in to provision eight cells during $530 \mathrm{~min}$ of hunting, an average of $13.6 \mathrm{~min}$ per prey. However, five cell-provisioning sequences only took $35-45 \mathrm{~min}$ to complete, an average of 8.5 
min per prey. On some occasions the female was seen to drag the prey along the log for 2-5 min.

As soon as the last prey was brought in, the wasp carried in loads of mud and sand to make a mud wall and close the cell. We observed female Symmorphus cristatus chewing on stems of Salix orestera and $S$. boothii and it is therefore possible that wasps incorporate willow fibers into the walls. Wasps gathered mud and water from creek banks about $30 \mathrm{~m}$ away. They gathered dry sand from areas near the nest log, wetting it into a ball after visiting the creek. About six trips were needed for wasp females to make the wall. In most cases material was quickly deposited and the wasp left immediately to gather more material. Only after several trips did the wasp remain in the nest to work material into an effective barrier. Wall construction lasted 25 to $100 \mathrm{~min}$. After completing a cell, female wasps left the nest area for a long period averaging $47 \mathrm{~min}$.

After closing the last cell, the wasp plugged the nest from the outside by bringing in loads of mud, wet and dry sand. As the plug was completed she shaped the exterior surface into a slightly raised dome. Wasps required 20-65 min for this task. About 10 trips were needed for each plug. Wasps always built an empty "vestibule" chamber between the last capped cell and exterior plug.

Evidence for competition and kleptoparasitism.-We observed aggressive, territorial conflicts between females over nesting sites and between males for breeding areas. These interactions provide a mechanism to support our second hypothesis, that wasps compete for nest sites in dense populations.

Antagonistic interactions were observed on a few occasions. In cases where a resident wasp encountered an intruding conspecific, the intruder left quickly. Afterwards, the resident wasp backed into the hole. In one case, we observed a complete nest usurpation. After one wasp had filled a nest, another appeared and chewed open the entrance plug. Making numerous trips for water, she removed the plug at the entrance hole and over the next hour pulled out loads of mud and prey, apparently emptying the nest almost completely. On a final survey of nest holes we discovered two other open nests that had previousiy been plugged completely.

Males remained close to the nest-log where they had been marked. We observed no migration between two logs $100 \mathrm{~m}$ apart. Resident males drove off other males that approached their log. These observations suggest that males do not move freely among different nest logs and that they actively defend a nest log. Males were observed flying towards female wasps until they hit them with their legs. They also were observed to lunge at and hit third instar Chrysomela aeneicollis larvae on willow foliage $2 \mathrm{~m}$ from the nest tree.

Natural holes that are used by Symmorphus cristatus ranged from 2-6 mm in external diameter. Most were on the sides or underside of the log. Six of 34 holes in this diameter range were open at the end of the 1998 season. These six included at least four that had been plugged earlier in the season. At the end of 1999 season, 44 of 47 holes in this size range were occupied by $S$. cristatus.

Cuckoo wasps (Chrysis nitidula) were often present on the nest-log, usually when the log was in full sun. We saw cuckoo wasps entering wasp holes on ten occasions. An average Symmorphus cristatus nest under construction was likely to be entered once in $10 \mathrm{~h}$. We saw no evidence that cuckoo wasps chew open barriers or plugs to gain access to nest chambers. To successfully parasitize a chamber, they must enter the nest while a chamber is being provisioned, before the mud barrier is complete. The $S$. cristatus females did not respond aggressively to the presence of cuckoo wasps. In six cases where the $S$. cristatus females returned to a nest shortly after a cuckoo wasp visit, she continued her normal provisioning 
behaviors. However, a female that had encountered a cuckoo wasp leaving her nest capped a cell that contained only three prey, well below the normal prey number per cell (Table 2).

\section{PREY USE AND NEST ARCHITECTURE}

Contents of trap nests collected.-Three trap-nests filled by Symmorphus cristatus filled at Big Pine Creek in 1997 were destroyed by mold growth while overwintering in the field. The fourth trap contained six developing wasp pupae, three of which emerged successfully as adults. In 1998 one Big Pine Creek trap was emptied, leaving only marks to show where the walls had been. There was no kleptoparasitism by Chrysis nitidula in trap-nests at either site. Trap-nests set out at Sebastopol contained a variety of insects (Table 3). Of 45 traps set out at Sebastopol, 25 were occupied by Hymenoptera of five other species.

Prey use by Symmorphus cristatus.-All trap-nests collected at Big Pine Creek contained third instar Chrysomela aeneicollis larvae (Table 2). Chrysomela aeneicollis is the only chysomeline leaf beetle that occurs in this region. Wasps at Sebastopol primarily provisioned their nests with Plagiodera californica larvae. Of 15 traps filled by $S$. cristatus females, 12 contained exclusively third instar $P$. californica larvae. One trap contained $112 P$. californica larvae and one second instar Chrysomela schaefferi larva. Finally, two traps (collected in the same week) contained mostly $C$. schaefferi, ( 74 of 91 larvae) with a few $P$. californica larvae in each cell (Table 2). Beetle larvae in provisioned nests were alive and produced secretion when prodded.

Nest architecture. - In support of our third hypothesis, we found evidence that these populations differ significantly in nest architecture. The proportion of intercalary cells (empty cells between provisioned cells) was more than four times greater in nests from Sebastopol (mean $=0.24, \mathrm{SE}=0.04$ ) than those from Big Pine Creek (mean $=0.05, \mathrm{SE}=0.05, F_{1,22}$ $=9.8, \mathrm{P}=0.005$ ). Trap-nests containing mixed Chrysomela schaefferi and Plagiodera californica larvae did not have intercalary cells. There was no difference between the populations in the amount of prey biomass per cell, although populations used different prey species (Table 4).

In support of our fourth hypothesis, larger cells were found in the innermost (rear) portion of the nests (Fig. 1, Table 4A). However, there was no overall relationship between cell position and prey biomass (Table $4 \mathrm{~B}$ ). The significant cell-by-trap interaction term in Table $4 \mathrm{~B}$ indicates that the relationship between cell position and prey mass differed among traps (i.e., greater prey mass was found in the inner cells of some traps and in the outer cells of others). Individual traps (with any influence of population statistically removed) differed significantly in cell length. All trap-nests contained at least one empty vestibular cell before the mud plug. Partitioning walls were uniformly thin, ranging from $0.5-2 \mathrm{~mm}$. Three of the Sebastopol traps showed faint marks where walls appeared to have been built and then partially removed.

Prey chemistry results. - In support of our fifth hypothesis, we found that Symmorphus cristatus will use chrysomeline prey with different types of larval secretion. The larval secretion of Chrysomela schaefferi contained salicylaldehyde as major component and traces of benzaldehyde. The monoterpene (epi)plagiolactone was a major component of the larval secretion of Plagiodera californica. The predominant ions of the mass spectrum of this major component were $\mathrm{m} / \mathrm{e} 164\left(\mathrm{M}^{+}, 53 \%\right), 136(16), 121$ (28), 108 (33), 107 (42), 93 (32), 91 (36), $80(66), 79(100), 77(46), 65$ (17). No salicylaldehyde was found in the larval secretion of $P$. californica.

\section{Discussion}

In this study we describe the natural history and nesting behavior of two populations of Symmorphus cristatus. Our observations supported the five hypotheses outlined in the in- 
TABLE 2.-Mean (SD) number of cells, number and mass of prey and cell sizes for artificial trap-nests collected in Big Pine Creek and Sebastopol

\begin{tabular}{|c|c|c|c|c|c|c|c|c|c|c|}
\hline \multirow[b]{3}{*}{ Locality } & \multirow[b]{3}{*}{ Prey } & \multirow{3}{*}{$\begin{array}{c}N \\
\text { Traps }\end{array}$} & \multirow{3}{*}{$\begin{array}{c}\text { Cell } \\
\text { number }\end{array}$} & \multirow{3}{*}{$\begin{array}{l}\text { Occupied } \\
\text { cell } \\
\text { number }\end{array}$} & \multicolumn{3}{|c|}{ Prey data } & \multirow{2}{*}{\multicolumn{3}{|c|}{ Cell length data $(\mathrm{mm})$}} \\
\hline & & & & & \multirow{2}{*}{$\begin{array}{l}\text { Larvae } \\
\text { per cell }\end{array}$} & \multirow{2}{*}{$\begin{array}{c}\text { Mass per } \\
\text { prey } \\
\text { larva }(\mathrm{mg})\end{array}$} & \multirow{2}{*}{$\begin{array}{l}\text { Prey mass per } \\
\text { cell }^{2}(\mathrm{mg})\end{array}$} & & & \\
\hline & & & & & & & & Occupied & Intercalar & Vestibular \\
\hline & C. aeneicollis & $\begin{array}{l}1 \\
0\end{array}$ & $7.1(1.7)$ & $5.0(1.5)$ & $4.8(1.5)$ & $17.6(3.4)$ & $84.6(27.8)$ & $14.5(4.1)$ & $7.0(2.1)$ & $\begin{array}{c}23.8 \\
(23.2)\end{array}$ \\
\hline Sebastopol & P. californica & 9 & $12.7(2.4)$ & $5.8(2.7)$ & $15.9(2.5)$ & $5.1(0.1)$ & $92.7(7.5)$ & $12.2(3.0)$ & $4.5(3.1)$ & $13.1(8.6)$ \\
\hline Sebastopol & P. califormica and $C$. schaeffert & 2 & $6.5(0.7)$ & $4.5(2.1)$ & $11.4(4.2)$ & $14.4(4.4)$ & 165.6 (no SD) & $19.1(6.6)$ & None & 4 (no SD) \\
\hline
\end{tabular}

I Individual prey mass determined from $6 C$. aeneicollis traps with 82 larvae, $3 P$. califomica traps with 107 larvae, and 1 trap with 46 mixed larvae of $P$. californica and $C$. schaefferi.

${ }^{2}$ Estimated by multiplying the average mass per intact prey larva by the number of larvae (intact and partially eaten) in the cell (see text)

${ }^{s}$ Data is for traps containing a mixture of both prey species 
TABLE 3.-Species using trap-nests set out at Big Pine Creek and Sebastopol in 1997 and 1998

\begin{tabular}{|c|c|c|c|}
\hline Population & Year & Trap-nests & Species in trap-nests \\
\hline & & & $\begin{array}{l}\text { Symmorphus crislatus } \\
\text { empty }\end{array}$ \\
\hline & 1998 & & $\begin{array}{l}\text { S. cristatus } \\
\text { empty }\end{array}$ \\
\hline \multirow[t]{10}{*}{ Sebastopol } & 1997 & & S. cristatus \\
\hline & & & Colletidae (bee) \\
\hline & & & $\begin{array}{l}\text { Ancistrocerus catskill halophila Viereck (Vespi- } \\
\text { dae: Eumeninae) }\end{array}$ \\
\hline & & 8 & Forficulidae \\
\hline & 1998 & 12 & S. cristatus \\
\hline & & 3 & Megachile bee \\
\hline & & 1 & Tracheliodes foveolineatus Viereck (Sphecidae) \\
\hline & & 1 & A. catskill halophila \\
\hline & & 5 & Forficulidae \\
\hline & & 3 & empty \\
\hline
\end{tabular}

troduction. First, we observed that wasps exhibit a defined set of behaviors to capture beetle larvae and provision their nests. Second, our observations of nesting behavior and trap-nest occupancy supported the hypothesis that wasps compete for nesting sites both intra and interspecifically. Intraspecific competition is likely to occur in the montane habitat of Big Pine Creek, where there is low insect species diversity and where Chrysomela aeneicollis populations are especially dense. Interspecific competition is more likely in Sebastopol, where insect diversity is greater and leaf beetles are less abundant. Third, we found signif-

TABLE 4.-Analyses of covariance for cell length and for the mean prey mass per cell. The trap-nest (population) effect in the ANCOVA tests whether significant variation exists among individual trapnests, independent of differences among populations. Cell number was the covariate in both analyses, and interactions between categorical variables and covariate test for differences among populations in the linear relationship between covariate and dependent variable. The continuous variables were log transformed before analysis

\begin{tabular}{lrll}
\hline \multicolumn{1}{c}{ Effect } & df & MS & F \\
\hline A. Cell length (all cells included) & & & \\
Population & 1 & 0.03529 & 1.2 \\
Trap-nest (population) & 22 & 0.03265 & $5.7^{* * *}$ \\
Cell number & 1 & 0.25721 & $45.0^{* * *}$ \\
Erfor & 104 & 0.00570 & \\
B. Prey mass per cell (only cells with prey larvae included) & & \\
Population & 1 & 0.07038 & 1.1 \\
Trap-nest (population) & 7 & 0.09268 & $5.4^{* *}$ \\
Cell number & 1 & 0.01709 & 1.3 \\
Cell number $\times$ Population & 1 & 0.01533 & 0.31 \\
Cef number $\times$ Trap-nest & 7 & 0.06766 & $5.3^{* *}$ \\
Ernor & 19 & 0.01288 & \\
\hline
\end{tabular}

** $P<0.005, * * * P<0.001$ 


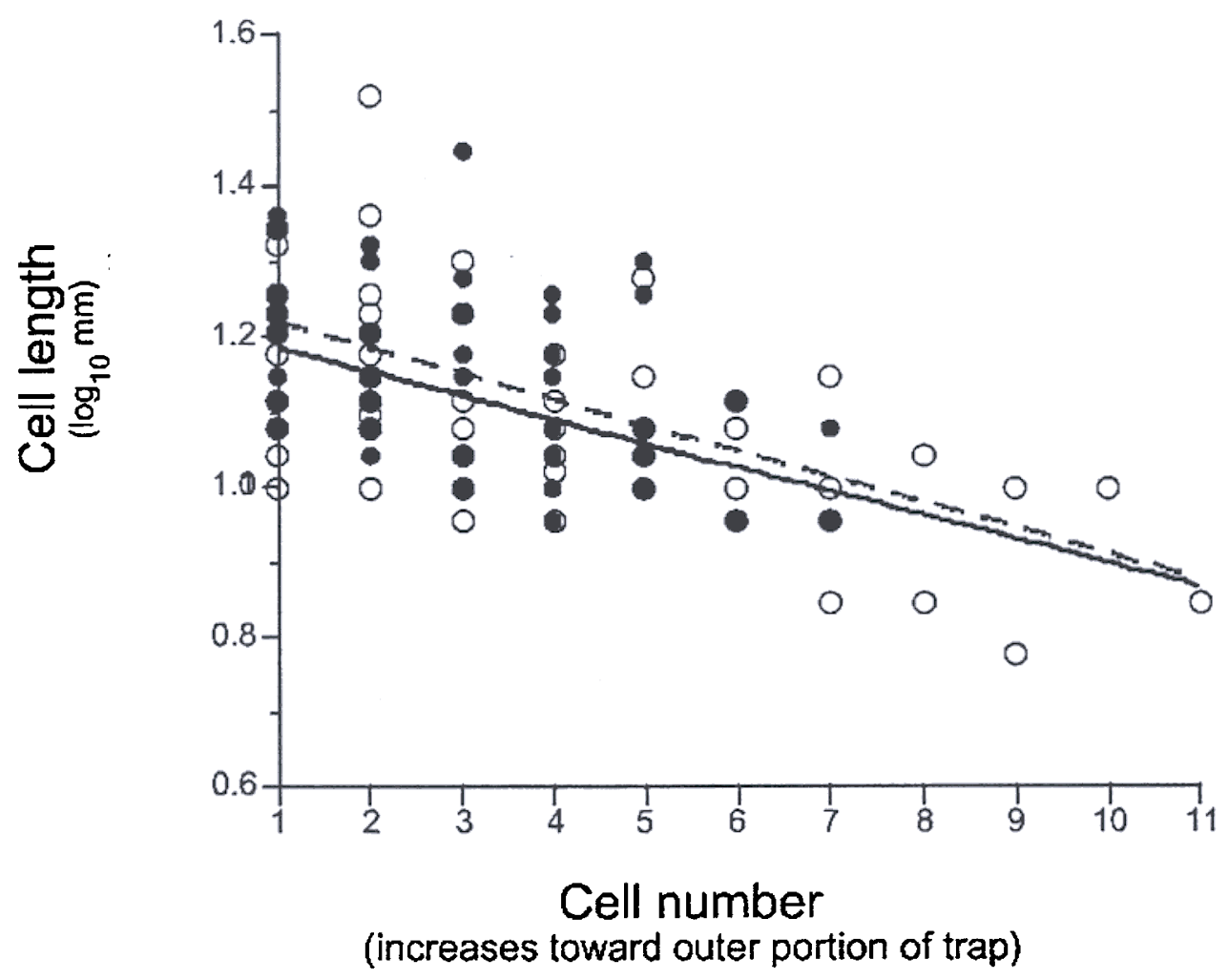

FIG. 1.-Relationship between cell number and cell length for traps from Big Pine Creek (filled circles, solid line) and Sebastopol (open circles, dotted line). The slope and intercept of the lines are estimated within the ANCOVA model. Cell number increases towards the rear of the trap. Cells in the outer portion of the traps were smaller for both Symmorphus cristatus populations.

icant differences in nest architecture between populations. Big Pine Creek nests had significantly fewer intercalary cells than Sebastopol nests. Fourth, we found support for our hypothesis that inner cells of $S$. cristatus nests are larger than outer cells, but we also found that inner cells are not provisioned with more prey than outer cells. Fifth, we found that $S$. cristatus will use chrysomeline beetles with autogenous monoterpene-based defensive secretions, as well as those with host-derived salicylaldehyde-based secretions. Within a given population, $S$. cristatus may use both types.

Whereas some wasp species are limited by availability of nectar-producing plants to feed adult wasps (Polis et al., 1998), most species are limited by competition for nesting sites, prey availability or by parasitoids (Krombein, 1967; Itino, 1997). We observed three behavioral mechanisms for intraspecific competition in Symmorphus cristatus. First, females competed directly for empty nesting sites, grappling together if a claimed hole was visited by another female. Second, we observed cases where a female completely emptied the nest of another wasp (nest usurpation). We also found previously filled nests that had been reopened. Third, male wasps displayed aggressive territoriality. This type of intraspecific aggression and nest usurpation by cavity-dwelling eumenine wasps was also reported by Cowan (1981) for Ancistrocerus adiabatus Saussure and Euodynerus foraminatus Saussure. If nesting 
sites are a limiting resource, as is hypothesized for other cavity-dwelling hymenopterans (Itino, 1997; Barthell et al., 1998), this conflict is not surprising. However, as there were always a few suitable holes remaining at the end of the nesting season, the $S$. cristatus population at Big Pine Creek is probably not entirely limited by nesting sites.

The wide diversity of insects that used Sebastopol trap-nests indicates that Symmorphus cristatus may be affected by interspecific competition for nesting sites. Barthell et al. (1998) found that exotic Megachilid bee and earwig species compete for nesting sites with native cavity-dwelling bees and wasps in central California. If competitors are able to supersede or displace $S$. cristatus individuals, they will limit reproductive capability of $S$. cristatus. We found little evidence of other density-dependent limiting factors in Sebastopol, as prey and nectar plants are plentiful, and we observed no kleptoparasites or parasitoids within trapnests.

Kleptoparasitism by cuckoo wasps limits reproduction of Symmorphus cristatus in Big Pine Creek. We observed large numbers of Chrysis nitidula around the $S$. cristatus nesting $\log$ and watched them repeatedly enter holes during cell provisioning. Curiously, $S$. cristatus does not seem to have a behavioral defense to these assaults. Several species of chrysids are known to parasitize $S$. cristatus nests throughout their range (Krombein, 1979; Parker and Bohart, 1966), along with several fly species (Evans, 1973; Godfrey and Hilton, 1983). Itino (1997) found that nest parasitism was one of the primary factors determining population density in four species of eumenine wasps in Japan.

Big Pine Creek and Sebastopol wasp populations differed significantly in their degree of cell occupancy. Big Pine Creek wasps provisioned $73 \%$ of cells in their nests and Sebastopol wasps (excluding the two nests that contained mixed species) only provisioned $53 \%$ of their cells, building nests with significantly more intercalary cells. Fye (1965), Krombein (1967) and Evans (1973), all remarked that the presence of intercalary cells is characteristic of Symmorphus cristatus nests. Krombein hypothesized that intercalary cells produced by contemporary wasps represent a relictual behavior. He proposed that the ancestral behavior was to make nests with a single provisioned cell and a single vestibular cell. In his view, vestibular cells may deter nest-predators and parasites, and he reasoned that when wasps found a long cavity, they would build a series of these provisioned/empty cell units. Eventually, the trait of linear nest-building behavior became fixed in the population. Whatever their origins, intercalary cells are rarely used by other trap-nesting wasps and it is not surprising that some populations appear to have reduced the number of intercalary cells.

Fye (1965) was the first to describe the nest architecture of Symmorphus cristatus quantitatively. He noted differences in cell length and provisioning from rear to front of the trap and inferred that this is a reflection of the large size of female wasps compared to male wasps, (female eggs tend to be laid at the rear of the trap). In this study we did not determine the sex of wasp offspring in each cell. However, we were able to statistically verify Fye's observation that the size of provisioned cells decreases toward the outer portion of the trap. Unlike Fye and other researchers (Fabre, 1921; Krombein, 1967), we did not find a relationship between mass of stored beetle larvae and cell position. Our evidence suggests that female $S$. cristatus do not significantly discriminate in the amount of food they provide offspring of either sex. Cowan (1981) found that the level of provisioning was closely correlated with adult size of offspring for Ancistrocerus adiabatus and Euodynerus foraminatus. Larger females were able to provision more offspring and larger males were able to copulate more frequently. Given these results, it will be important and interesting to test the degree of sexual size dimorphism and within-sex size variance for $S$. cristatus, as it compares to other closely-related species.

Although Chrysomela aeneicollis larvae are much larger than Plagiodera califormica larvae, 
wasps in the two populations stocked their cells with approximately the same mass of provisions. The exception to this occurred when Sebastopol trap-nests were provisioned with a mixture of Chrysomela schaefferi and $P$. californica larvae. In these mixed nests the number of larvae per cell was approximately the same as if it had been stocked with $P$. californica, but the greater mass of each $C$. schaefferi larva resulted in a doubling of prey mass per cell. In this case, the number of prey per cell appears to be linked to the mass of the primary prey species. As the Sierra population of Symmorphus uses fewer prey to provision each cell than Sebastopol wasps, this study provides evidence for local adaptation in prey provisioning.

Symmorphus cristatus has primarily been documented to use chrysomeline prey species with salicylaldehyde-based secretions. We discovered that besides using the salicylaldehydeproducing Chrysomela schaefferi (a new prey record), S. cristatus also uses Plagiodera californica, which has a monoterpene-based secretion. This is the first record of $S$. cristatus using a prey with this type of chemical defense, and it is the first evidence that individual $S$. cristatus females will use larvae with different forms of chemical defense to provision their offspring. Pasteels and Gregoire (1984) found that sawflies (Tenthredo olivacea) could attack two prey species with different chemical defenses, but seemed to hunt for only one type at a time. A conditioning process was needed to switch prey types. This was unlikely to have occurred in Sebastopol, where at least one female incorporated both types of larvae into individual cells. Our study shows that $S$. cristatus populations are not obligately specialized on one particular defensive compound.

Like the "coevolutionary arms-race" proposed by Ehrlich and Raven (1964) to explain the diversification of flowering plants and insect herbivores, specialist predators such as Symmorphus may affect the evolution of chemical defense in their prey. Chrysomeline larval defensive secretions are effective against many generalist predators (Wallace and Blum, 1969; Pasteels and Gregoire, 1984; Kearsley and Whitham, 1992; Rank et al., 1996). This has been taken as evidence to explain host plant specialization in herbivores whose defensive secretion is sequestered from host-plant chemicals (Denno et al., 1990; Kearsley and Whitham, 1992). Symmorphus wasps, as specialists, are not repelled by the beetle's chemical defenses (Fabre, 1891; Devantoy, 1948; Rank et al., 1996). Like the specialized syrphid fly larvae (Parasyrphus sp.) that also prey on chrysomeline larvae (Rank and Smiley, 1994; Rank et al., 1996; Köpf et al., 1997), these wasps may use their prey's secretion to find them.

Acknowledgments. - We thank K. Smiley for many hours of observing wasps and R. and S. Smiley for helping us find wasps and helping with logistics in the John Muir Wilderness. We also thank the managers of the Inyo National Forest for permission to carry out this study. The University of California White Mountain Research Station provided an essential base for this research, including laboratory space, accommodations, technical help with GIS and financial support. Their long-term support has been crucial to the overall success of this research. Thanks also to R. M. Bohart and R. W. Thorp for wasp and bee identification and to D. Freidel for geographical data. R. Waugaman, C. D. Hulsey and two anonymous reviewers provided helpful comments on the manuscript.

\section{LITERATURE CTTED}

BARTHELL, J. F., G. W. FRANKIE AND R. W. THORP. 1998. Invader effects in a community of cavity nesting megachilid bees (Hymenoptera: Megachilidae). Environ. Entomol., 27:240-247.

Berland, L. 1928. Hymenopteres Vespiformes II (Eumenidae, Vespidae, Masaridae, Bethylidae, Dryinidae, Embolemidae). Office Central de Faunistique, Paris. p. 19-24.

BlüthGen, P. 1961. Die Falten wespen Mitteleuropas (Hymenoptera, Diploptera). Akademie Verlag, Berlin. 248 p.

BONELLI, B. 1989. On nesting behavior of Symmorphus crassicornis (Panzer) and Ancistrocerus antilope 
(Panzer), with a short description of a Delta unguiculatum Vill. Nest. Boll. Entomol. Bologna, 43:89-98.

CHILCUTT, C. F. AND D. P. CoWAN. 1993. Methods for artificial rearing of solitary eumenid wasps (Hymenoptera: Vespidae: Eumeninae). Great Lakes Entomol., 26:15-19.

Cowan, D. P. 1981. Parental investment in two solitary wasps Ancistrocerus adiabatus and Euodynerus foraminatus (Eumenidae: Hymenoptera). Behav. Ecol. Sociobiol., 9:95-102.

Cumminc, J. M. 1989. Classification and evolution of the eumenine wasp genus Symmorphus Wesmael (Hymenoptera: Vespidae). Mem. Entomol. Soc. Can., Number 148.

DeNnO, R. F., S. LARSSON AND K. L. OlmSTEAD. 1990. Role of enemy-free space and plant quality in host-plant selection by willow beetles. Ecology, 71:124-137.

DETINER, K. AND G. SCHWINGER. 1987. Chemical defense in the larvae of the leaf beetle Gonioctena viminalis. L. (Coleoptera: Chrysomelidae). Experientia, 43:458-460.

Devantoy, J. 1948. Les Prédateurs et les parasites de la chysomèle du peuplier. Feulle Nat., 3:85-89.

EHRuICH, P. R. AND P. H. RAVEN. 1964. Butterflies and plants: a study in coevolution. Evolution, 18:586608.

EISNER, T. AND J. MEINWALD. 1966. Defensive secretions of arthropods. Science, 153:1341-1350.

Evans, H. E. 1973. Further studies on the wasps of Jackson Hole, Wyoming (Hymenoptera, Aculeata). Great Basin Nat., 33:147-155.

FABRE, J. H. 1891. Souvenirs entomologiques v.4. Delagrave, Paris. p. 168.

FABRE, J. H. 1921. More hunting wasps. Tr. by A. Teixeira de Mattos. Dodd, Mead and Company, New York. $376 \mathrm{p}$.

FYE, R. E. 1965. The biology of the Vespidae, Pompilidae, and Sphecidae (Hymenoptera) from trap nests in northwestern Ontario. Can. Entomol., 97:716-744.

GODFREY, S. AND D. F. J. HILTON. 1983. Nesting biology of solitary wasps and bees in the eastern townships region, Quebec. Can. Field Nat., 97:1-8.

HaMANISHI, Y. 1996. Cleptoparasitic life of the Tachnid fly, Symmorphomyia katayamai Mesnil et Shima, in the nest of host wasps hunting the chrysomelid-larva prey. Jap. J. Entomol., 64:843-860.

Hinton, H. E. 1951. On a little known protective device of some chrysomelid pupae (Coleoptera). Proc. R. Entomol. Soc. London (A), 26:67-73.

HolT, R D. 1977. Predation, apparent competition, and the structure of prey communities. Theor. Popul. Biol., 12:197-229.

ITINO, T. 1997. Comparative behavioral ecology and population dynamics of eumenid wasps. Mem. Agric. Kagawa Univ., 62:1-206.

JEFFERES, M. J. AND J. H. LAWTON. 1984. Enemy-free space and the structure of ecological communities. Biol. J. Linn. Soc.-London, 23:269-286.

JOLIVET, P. 1950. Les parasites, prédateurs et phorétiques des Chrysomeloidea (Coleoptera) de la faune Franco-Belge. Bull. R. Sci. Nat. Belge., 26:1-39.

KEARSLEY, M. J. C. AND T. G. WhITHAM. 1992. Guns and Butter: a no cost defense against predation for Chrysomela confluens. Oecologia, 92:556-562.

KóPf, A., N. E. RANK, H. RoININEN AND J. TAHVANAINEN. 1997. Defensive larval secretions of leaf beetles attract a specialist predator Parasyrphus nigritarsis. Ecol. Entomol., 22:176-183.

KrombeIN, K V. 1967. Trap-nesting wasps and bees: life histories, nests, and associates. Smithsonian Institution Press, Washington. p. 122-126.

P. D. HURD, D. R. SMITH AND B. D. BRooks. 1979. A catalogue of Hymenoptera north of Mexico. Smithsonian Institution Press, Washington, D.C. p. 1505-1507.

MATSUDA, K. AND F. SUGAWARA. 1980. Defensive secretion of Chrysomelid larvae Chrysomela vigintipuctata costella (Marseul), C. populi L. and Gastrolina depressa Baly (Coleoptera: Chrysomelidae). Appl. Entomol. Zool., 15:316-320.

MEINWALD, J., T. H. JONES, T. EISNER AND K. Hicks. 1977. New methycyclopentanoid terpenes from larval defensive secretion of a chrysomelid beetle (Plagiodera versicolora). Proc. Nat. Acad. Sci. U.S.A., 74:2189-2193.

PARKER, F. D. AND R. M. BOHART. 1966. Host-parasite associations in some twig-nesting Hymenoptera from Western North America. Pan-Pacific Entomol., 42:91-98. 
PASteels, J. M., J.-C. Braekman, D. Daloze and R. OTtinger. 1982. Chemical defense in chrysomelid larvae and adults. Tetrahedron, 38:1891-1897.

- M. Rowell-Rahier, J. C. BRaEkMan AND A. DUPONT. 1983. Salicin from host plant as precursor of salicylaldehyde in defensive secretion of chrysomeline larvae. J. Physiol. Entomol., 8:307314.

- AND J. C. GREGOIRE. 1984. Selective predation on chemically defended chrysomelid larvae: a conditioning process. J. Chem. Ecol., 10:1693-1700.

M. Rowell-Rahier, J-C. BrafkMan and D. Daloze. 1984. Chemical defenses in leaf beetles and their larvae: the ecological, evolutionary and taxonomic significance. Biochem. Syst. Ecol., 12:395-406.

POlIS, G. A., S. D. HURD, C. T. JACKSON AND F. SANCHEZ-PINERO. 1998. Multifactor population limitation: variable spatial and temporal control of spiders on Gulf of California islands. Ecology, 79:490 502.

RANK, N. E. AND J. T. Smiley. 1994. Host-plant effects on Parasymhus melanderi Curran (Diptera: Syrphidae) feeding on a willow leaf beetle Chrysomela aeneicollis Schaeffer (Coleoptera: Chrysomelidae). Ecol. Entomol., 19:31-38.

- J. T. SMILEY AND A. KóPF. 1996. Natural enemies and host plant relationships for leaf beetles (Chrysomelinae) feeding on Salicaceae and Betulaceae, p. 147-192. In: P. H. Jolivet, and M. L. Cox (eds.). Chrysomelidae biology, Vol 1. Ecological SPB Publishing, Amsterdam. 465 p.

Richards, O. W. 1980. Scolioidea, Vespoidea and Sphecoidea. Hymenoptera, Aculeata. Handbooks for the identification of British insects 6, Part 3(b):1-118.

SMEREKA, E. P. 1965. The life history and habits of Chrysomela crotchi Brown (Coleoptera: Chrysomelidae) in Northwestern Ontario. Can. Entomol, 97:541-549.

SMILEY, J. T., J. H. HORN AND N. E. RANK. 1985. Ecological effects of salicin at three trophic levels: new problems from old adaptations. Science, 229:649-651.

AND N. E. RANK. 1986. Predator protection versus rapid growth in a montane leaf beetle. Oecologia, 70:106-112.

AND $\longrightarrow$. 1991. Bitterness of Salix along the north fork of Big Pine Creek, eastern California: species and community elevational trends, p. 132-147 In: C. A. Hall, and V. Doyle-Jones (eds.). Natural History of the Eastern California and High-altitude Research, White Mountain Research Station Symposium, Vol. 3. 25 p.

SMITH, F. 1858. Catalogue of British fossorial Hymenoptera, London. p. 200.

Sugawara, F., K. Matsuda, A. Kobayashi AND K. Yamashita. 1979. Defensive secretion of chrysomelid larvae Linaeidea aenea L. and Plagiodera versicolora distincta Baly. J. Chem. Ecol., 5:929-934.

WALLACE, J. B. AND M. S. BLUM. 1969. Refined defensive mechanisms in Chrysomela scripta. Ann. Entomol. Soc. Amer., 62:503-506.

YAMANE, Y. 1990. A revision on the Japanese Eumenidae (Hymenoptera, Vespoidea). Insecta Matsumerana, 43:1-189. 